\title{
Motivations for alcohol consumption during the COVID-19 pandemic in Islamic Republic of Iran
}

Abolfazl Fattah, ${ }^{1}$ Maliheh Khalvati, ${ }^{2}$ Mahdi Abounoori, ${ }^{3}$ Nader Molavi, ${ }^{4}$ Fatemeh Azartash ${ }^{5}$ and Masoudeh Babakhanian ${ }^{3}$

${ }^{1}$ Department of Internal Medicine, School of Medicine, Semnan University of Medical Sciences, Semnan, Islamic Republic of Iran. ${ }^{2}$ Paramedical Faculty, Mashhad University of Medical Sciences, Mashhad, Islamic Republic of Iran. ${ }^{3}$ Social determinants of health Research center, Semnan university of medical sciences, Semnan, Islamic Republic of Iran. ${ }^{4}$ Department of Addiction Studies, School of Medicine, Kashan University of Medical Sciences, Kashan, Islamic Republic of Iran. ${ }^{5}$ Department of Psychiatry, Islamic Azad University of Khorasgan, Isfahan, Islamic Republic of Iran. (Correspondence to: Masoudeh Babakhanian: Babakhanian.m@gmail.com).

\begin{abstract}
Background: High alcohol consumption is an important public health problem, and understanding factors associated with such consumption is essential.

Aims: This study aimed to assess individual and social factors associated with alcohol consumption during the coronavirus disease 2019 (COVID-19) pandemic in the Islamic Republic of Iran.

Methods: In this qualitative study, purposive sampling was used to select study participants by sharing the survey link on the Telegram application channels with an Iranian audience during COVID-19. The study was conducted from March to June 2020 and reached all Iranian provinces. We used qualitative content analysis to investigate specific concepts in the responses.

Results: Of the 116 participants who responded to the survey, 34 (29.3\%) were females, and 82 (70.7\%) were male. The mean age of the participants was 34.8 years (standard deviation 9.9; range 17-71 years). Most of the participants (75.9\%) reported having consumed alcohol, and 56.9\% reported having self-medicated for an illness without a doctor's prescription before the COVID-19 pandemic. The most common reason given for alcohol consumption was to relieve stress during home quarantining $(32.3 \%$ ). Based on analysis of the responses, two themes emerged: coping motivations and coping skills, with five subthemes and 14 basic codes. Coping motivations were more powerful than coping skills in relation to high alcohol consumption.
\end{abstract}

Conclusion: Poor coping skills and strong motivations, combined with misinformation on social media and the internet, appear to have led to new or higher alcohol consumption among survey respondents.

Keywords: Alcohol drinking, COVID-19, motivation, social media, Iran

Citation: Fattah A; Khalvati M; Abounoori M; Molavi N; Azartash F; Babakhanian M. Motivations for alcohol consumption during the COVID-19 pandemic in Islamic Republic of Iran. East Mediterr Health J. 2022;28(2):108-113. https://doi.org/10.26719/emhj.22.024

Received: 12/11/20; accepted: 15/06/21

Copyright $@$ World Health Organization (WHO) 2022. Open Access. Some rights reserved. This work is available under the CC BY-NC-SA 3.0 IGO license (https://creativecommons.org/licenses/by-nc-sa/3.o/igo)

\section{Introduction}

In the field of public health, high alcohol consumption has attracted considerable attention. In the laws of the Islamic Republic of Iran, drinking alcohol is considered against sharia and a crime; therefore, alcohol consumption in the country is a new and challenging topic. Despite the ban, alcohol is sold illegally in the Islamic Republic of Iran, either through illegally produced local products or illegal imports. This issue prevents policy-makers from addressing alcohol use effectively. Some profiteers prefer methanol to ethanol because it is less expensive and more readily available $(1,2)$. According to the World Health Organization (WHO), the Islamic Republic of Iran ranks 161 in total alcohol consumption per capita globally; however, among those who consume alcohol, the country ranks 9th in terms of the amount of alcohol consumed (3). WHO estimates the per capita alcohol consumption in the Eastern Mediterranean region to be 0.6 $\mathrm{L}$ of pure alcohol a year in the population older than 15 years (3). Although a very small minority of people in the
Islamic Republic of Iran consume alcohol, per capita alcohol consumption in the country has been estimated at $1.0 \mathrm{~L}$ a year (4).

In recent years, the age at starting to drink alcohol has dropped to 11 years in the Islamic Republic of Iran (5). Following the first official report of death due to coronavirus disease 2019 (COVID-19) in the country on 19 February 2020, the Iranian Ministry of Health and Medical Education provided information on preventive measures, including regular handwashing with soap and water or disinfection of hands and surfaces with alcohol solutions. According to the Iranian Centers for Disease Control, in 2020, a large number of people drank alcohol containing high levels of methanol (6) as a result of exposure to false information spread through social media about the role of alcohol, whether gargling or drinking, in preventing COVID-19 $(7,8)$. Data from the Legal Medicine Organization of the Islamic Republic of Iran show that more than 700 deaths occurred because of alcohol poisoning from 20 February to 7 April 2020. 
From 7 March to 8 April 2020, methanol poisoning was reported in all 31 provinces of the Islamic Republic of Iran, with deaths due to methanol consumption (ages $14-78$ years) in 26 provinces $(6,8,9)$. The total number of deaths due to alcohol poisoning from February to April 2020 was almost 11 times higher than the number of confirmed deaths due to the same cause for the same period in 2019 (66 deaths). Several factors contributed to this situation. First, many people with alcohol poisoning do not go to hospitals because they are afraid of being arrested (since alcohol use is illegal in the country); if they do go, they often arrive too late. In addition, many of the alcoholic drinks available in the black market in the Islamic Republic of Iran are counterfeit and are marketed under the names of well known brands. Many people lack knowledge of the various forms of alcohol and their consequences $(2,8,10)$.

Limited knowledge about the dangers of alcohol consumption, combined with fear of COVID-19, has harmful consequences (6). Misinformation, misunderstandings and rumours on social media and the internet can create contradictory messages. When combined with a lack of trust in official information channels, this makes people more vulnerable to information coming from informal communication channels (9).

In the Islamic Republic of Iran, health workers have been faced with a double burden: providing roundthe-clock care for COVID-19 patients and dealing with an unprecedented wave of poisoning due to alcohol consumption, reportedly taken to prevent COVID-19 (11). Because of the significance of alcohol use during the COVID-19 pandemic, we investigated why people in the Islamic Republic of Iran consumed alcohol during the pandemic. The results of this study will help health officials, counselors, and psychologists begin to tackle this problem.

\section{Methods}

\section{Study design and participants}

We conducted a qualitative study (from March to June 2020) with a content analysis approach to identify underlying reasons for alcohol consumption during the COVID-19 outbreak in the Islamic Republic of Iran.

Participants were primarily recruited using purposive sampling. The study was conducted in all 31 provinces of the country by sharing the Telegram application interview link, a global messaging service. The interview link was shared to Telegram channels with an Iranian audience who lived in the country (almost 10000 members). The survey in Farsi is available at: https://docs.google.com/forms/d/e/ 1FAIpQLScZAOQK6RjohLeDHm87CFehrInıZdSKUPhJ RnSJtJdSl_CurA/viewform?vc $=0 \& c=0 \& w=1 \& u s p=$ mail_ form_link\&urp=gmail_link. The English version is available at: https://docs.google.com/forms/d/e/1FAIpQL SellcKQSk1JenLRoyisbjVxDS6LeSOz9M3HcisNMoKRE4 $\mathrm{REfQ} /$ viewform.
Snowball sampling was also used whereby those interviewed were asked to send the link to other individuals who might be interested in participating in this research.

Only those who had attempted to consume a large amount of alcohol of unknown type or constituent (methanol, ethanol or other alcohol types) since the start of the COVID-19 pandemic were eligible to participate. Participation was voluntary, all answers remained confidential and the names of the participants were not mentioned in the study; instead, codes were used. Interviews were in Farsi.

\section{Definitions}

Coping is defined as cognitive and behavioral attempts to manage particular, continually changing, external and/or internal demands that are evaluated as taxing or exceeding the individual's resources (12).

High alcohol consumption is described as having an average of more than two drinks a day (for women) or more than four drinks a day (for men) (13).

Self-medication is defined as the application and administration of medicines by individuals (or members of their family) to treat self-diagnosed or self-recognized conditions or symptoms (14).

\section{Data analysis}

For data analysis, the qualitative content analysis method was used to investigate specific concepts in the responses. The primary data gathering method in this study was a semi-structured online text interview. We used an inductive approach to recognize themes within the interview data. The interviews were read and concepts coded. Then, the codes were classed based on their similarities. The advantage of online interviews is the possibility of conducting them individually with the research participant's full consent. In qualitative studies, the sample size must be sufficient to have a theoretical saturation; therefore, the interviews were continued until data were saturated.

\section{Ethical considerations}

Respondents gave their informed consent to participate, and their privacy and right to withdraw from the study at any time were assured. This study was approved by the Student Research Committee of Mazandaran University of Medical Sciences: research ethics code IR.MAZUMS. REC.1399.131.

\section{Results}

Our sample consisted of 116 people: 34 (29.3\%) females and $82(70.7 \%)$ males (Table 1). The mean age of the participants was 34.8 years (standard deviation 9.9 years, range 17-71 years). Most of the participants (75.9\%) reported having consumed alcohol before the survey (an average of more than two drinks a day for women or more than four drinks a day for men). In addition, 56.9\% reported 


\begin{tabular}{|c|c|c|c|}
\hline Variable & Males $(\mathbf{n}=\mathbf{8 2})$ & Females $(n=34)$ & Total $(n=116)$ \\
\hline Age in years, mean (SD) & $36.3(9.9)$ & $31.2(9.02)$ & 34.8 (9.9) (range 17-71) \\
\hline \multicolumn{4}{|l|}{ History of high alcohol consumption, no. (\%)a } \\
\hline Yes & $68(82.9)$ & $20(58.8)$ & $88(75.9)$ \\
\hline No & $14(17.1)$ & $14(41.2)$ & $28(24.1)$ \\
\hline \multicolumn{4}{|l|}{ History of self-medication, no. (\%) } \\
\hline Yes & $48(58.5)$ & $18(52.9)$ & $66(56.9)$ \\
\hline No & $34(41.5)$ & $16(47.1)$ & $50(43.1)$ \\
\hline \multicolumn{4}{|l|}{ Most common reasons for high alcohol consumption, no. $(\%)^{b}$} \\
\hline Protection from SARS-CoV-2 & $18(15.7)$ & $8(17.4)$ & $26(16.1)$ \\
\hline Having fun drinking alcohol & $15(13.0)$ & $2(4.3)$ & $17(10.6)$ \\
\hline Self-medication & $8(7)$ & $3(6.5)$ & $11(6.8)$ \\
\hline Poor warnings about the hazards of alcohol use from the health ministry & $5(4.3)$ & $7(15.2)$ & $12(7.5)$ \\
\hline Relieve stress of home quarantine & $37(32.2)$ & $15(32.6)$ & $52(32.3)$ \\
\hline Reduce fear of catching COVID-19 & $20(17.4)$ & $7(15.2)$ & $27(16.8)$ \\
\hline Scarcity of disinfectants & $7(6.1)$ & $4(8.7)$ & $11(6.8)$ \\
\hline Exposure to misinformation on social media and the Internet & $3(2.6)$ & $\mathrm{o}(0)$ & $3(1.9)$ \\
\hline Suicide or self-harm attempt & $2(1.7)$ & $\mathrm{o}(\mathrm{o})$ & $2(1.2)$ \\
\hline Total, no. (\%) & $115(100)$ & $46(100)$ & $161(100)$ \\
\hline
\end{tabular}

COVID-19= coronavirus disease 2019

${ }^{a}$ High alcohol consumption was defined as an average of more than two drinks a day (for women) or four drinks a day (for men) (14).

${ }^{b}$ Respondents could select more than one answer.

having self-medicated for an illness without a doctor's prescription before the COVID-19 pandemic, which could be an indication of their susceptibility to misinformation. The most common reason for high alcohol consumption of unknown types or constituents was to relieve stress during home quarantine $(32.3 \%)$. Other major reasons were relaxation to reduce the fear of catching COVID-19 (16.8\%), protection from SARS-CoV-2 (16.1\%) and having fun drinking alcohol (10.6\%) (Table 1).

All the participants were using alcohol as part of a coping mechanism. The reasons for use are as follows.

\section{First theme: coping motives}

In this theme, our participants gave various reasons for alcohol use during the COVID-19 pandemic (Table 2).

\section{Achieve a positive mood}

Achieving a positive mood during the pandemic was one of the major reasons for alcohol use. In the current pandemic, some participants believed drinking alcohol would help them not to think about everyday problems and stresses due to the pandemic and balance their mood. "Drinking alcohol relaxes me completely and makes me feel better when I'm tense," said one participant.

Many participants reported that they drank alcohol before the pandemic for fun and their drinking was not related to the pandemic.

\section{Alleviate negative emotions}

Some participants reported using alcohol to get rid of negative feelings. "I drink to get rid of myself," said one participant. Another said that they drank, "Because I'm stuck in the house and can't go out, I do it for joy without any reason."

\section{Second theme: coping skills}

People who drink alcohol as a type of "coping skill" may have limited skills to adapt and confront life's challenges.

\section{Exposure}

In our study, most of the participants with no history of alcohol use began drinking after the onset of the pandemic, mostly because of the widespread misinformation on social media about alcohol's role in preventing COVID-19 (Table 2). For example, some participants claimed that they saw posts on Instagram that everyone was drinking alcohol in the Islaminc Republic of Iran. As a result, they started drinking and continued because they liked it.

\section{Lack of knowledge}

Most young alcohol users lack knowledge about the dangers of drinking (Table 2). The health ministry warnings are not effective. On Iranian television, alcohol was presented as a good disinfectant against COVID-19, without mentioning the adverse effects of drinking alcohol. Thus, some participants thought that drinking it could prevent them from catching the disease. To their surprise, they felt happy and calm after drinking.

\section{Active coping strategies}

Drinking for some of the participants represented an active coping strategy (a practical plan to achieve a goal 


\begin{tabular}{|c|c|c|}
\hline Themes & Class & Basic codes \\
\hline \multirow[t]{2}{*}{ Coping motives } & Achieve a positive mood & $\begin{array}{l}\text { Relaxation; Have fun drinking alcohol; Reduce the stress of home quarantine; Reduce the } \\
\text { fear of catching COVID-19 }\end{array}$ \\
\hline & Alleviate negative emotions & Suicide attempt; Attempting self-harm \\
\hline \multirow[t]{3}{*}{ Coping skills } & Exposure to misinformation & $\begin{array}{l}\text { Extensive exposure to misinformation on social media and the internet; Easy access to } \\
\text { alcohol as a disinfectant }\end{array}$ \\
\hline & Lack of knowledge & $\begin{array}{l}\text { Consumer ignorance; Poor health ministry warning about alcohol hazards; Alcohol } \\
\text { consumption being taboo in the Islamic Republic of Iran }\end{array}$ \\
\hline & Active coping strategies & Protection from COVID-19; Self-medication; Scarcity of disinfectants \\
\hline
\end{tabular}

COVID-19= coronavirus disease 2019 .

with the belief that the strategy predicts better health outcomes). In the Islamic Republic of Iran, during the pandemic and with the resultant disinfectant shortages, some people tried to protect themselves and self-medicated by drinking alcohol (Table 2). Some of the participants said that they could not find any disinfectant at stores and pharmacies. They then found drinkable alcohol in the black market and started drinking it to avoid catching the disease.

\section{Discussion}

Our study was conducted to identify the reasons for alcohol consumption in the Islamic Republic of Iran. We extracted two main themes and several subthemes: coping motives (achieve a positive mood, alleviate negative emotions) and coping skills (exposure, lack of knowledge and active coping strategies). Since alcohol consumption is illegal in the country, most available types of alcohol are homemade or smuggled. During the pandemic, poor warnings about the harms of alcohol use by the health ministry and an abundance of misinformation may have resulted in widespread alcohol use. Because there are no guidelines on alcohol consumption or production, the risk of improper use of ethanol, adulterated ethanol and methanol poisoning increases. Alcohol consumption was more prevalent in men than women in our survey participants, which is consistent with the findings of other studies in the country $(15,16)$. The mean age of our participants was 34.8 years (range 17 to 71 years), which was is to previous studies ( 38 and 33 years, respectively) $(15,16)$.

The coping motivations are the main reasons for drinking alcohol and, based on the literature, these have been associated with alcohol use disorder (17-19). Achieving a positive mood and alleviating negative emotions were part of this theme. In a 2014 study the reasons given for alcohol consumption were based on wrong attitudes and beliefs such as beliefs that drinking alcohol brings happiness and strengthens the body (10). A 2002 study reported pleasure-seeking as a reason for drinking alcohol (20). In the context of alleviating negative emotions, we are faced with an increase in suicide attempts. A survey on suicide risk during the COVID-19 pandemic found the lockdown to escalate two known suicide precipitants, domestic violence and alcohol consumption (21).

Widespread exposure to social media and the internet influenced the coping skill of the study participants, in line with the previously mentioned 2014 study (10). Alcohol advertising creates a positive image in people's minds and leads them to start drinking alcohol or to drink more alcohol (22). The literature on management of information on COVID-19 confirms the spread of misinformation about virus transmission, the disease and its treatment (23), which has led people to drink alcohol to avoid catching the virus (9).

Some participants reported stress and anxiety as the reasons for drinking. According to social learning theory, in stressful situations, people with poor coping skills are drawn to drug and alcohol consumption (24). In our study, the participants had strong drinking motivation and poor coping skills, consistent with the results of a 2021 survey, which showed that people with high coping motivation and low coping skills reported higher alcohol consumption in stressful situations (24). An important problem during a crisis is the scarcity of and lack of access to necessities. Early in the COVID-19 pandemic, disinfectants, face masks and gloves were in short supply in the Islamic Republic of Iran. In this period, some people who did not have correct information about using alcohol as a disinfectant and for preventing the spread of the virus began drinking alcohol to disinfect their internal organs.

Our study has some limitations. First, we did not measure the exact amount of alcohol consumed, nor the exact type of alcohol used or its proof. Second, there may be selection bias with regard to the sample because the use of snowball sampling increases this risk. Third, the semi-structured nature of the interview may have influenced the participant's responses. Specific questions may have encouraged participants to address specific topics and not other topics. Fourth, our sample size was small and as such our results may underestimate alcohol consumption as a public health issue during the pandemic. Finally, this was a qualitative study; it is possible that our knowledge and previous experience about alcohol consumption influenced the interpretation of the interview content. 
The reasons for alcohol consumption are complex and extensive and include economic, social and cultural factors (25). Poor coping skills, strong motivations and misinformation on social media and the internet appear to have resulted in high alcohol consumption, causing social harm. Coping motivations and coping skills, which are concepts extracted from the data, are new concepts in the research on alcohol consumption in the Islamic Republic of Iran. Further research in this field is recommended and will help health officials, counsellors, and psychologists to tackle this issue of alcohol consumption in the Islamic Republic of Iran.

Funding: This study was supported by the Student Research Committee of Mazandaran University of Medical Sciences, grant number 131.

Competing interests: None declared.

\section{Les motivations en matière de consommation d'alcool pendant la pandémie de COVID-19 en République islamique d'Iran}

\section{Résumé}

Contexte: Une forte consommation d'alcool représente un problème de santé publique important; il est donc essentiel de comprendre les facteurs qui lui sont associés.

Objectifs : L'étude visait à évaluer les facteurs individuels et sociaux associés à la consommation d'alcool pendant la pandémie de maladie à coronavirus 2019 (COVID-19) en République islamique d'Iran.

Méthodes: Dans la présente étude qualitative, un échantillonnage ciblé a été utilisé pour sélectionner les participants. Pour ce faire, le lien de l'enquête a été partagé sur les canaux de l'application Telegram avec un public iranien pendant la pandémie de COVID-19. L'étude a été menée de mars à juin 2020 et a couvert toutes les provinces iraniennes. Nous avons utilisé une analyse qualitative du contenu pour étudier des concepts spécifiques figurant dans les réponses.

Résultats : Sur les 116 participants ayant répondu à l'enquête, 34 (29,3\%) étaient des femmes et 82 (70,7 \%) étaient des hommes. L'âge moyen des participants était de 34,8 ans (écart type 9,9; fourchette comprise entre 17 et 71 ans). La plupart des participants $(75,9 \%)$ ont déclaré avoir consommé de l'alcool et $56,9 \%$ ont déclaré s'être automédicamentés pour une maladie sans ordonnance médicale avant la pandémie de COVID-19. La raison la plus fréquemment invoquée pour justifier la consommation d'alcool était le soulagement du stress pendant la quarantaine à domicile (32,3\%). L'analyse des réponses a permis de dégager deux thèmes: les motivations à la consommation d'alcool et les capacités d'adaptation, avec cinq sous-thèmes et 14 codes de base. Les motivations prenaient le dessus sur les capacités d'adaptation dans le cas d'une forte consommation d'alcool.

Conclusion: De faibles capacités d'adaptation et de fortes motivations, associées à des informations erronées diffusées sur les médias sociaux et l'Internet, semblent avoir conduit à un nouvel usage de l'alcool ou à une consommation plus élevée chez les personnes interrogées.

$$
\begin{aligned}
& \text { الدو افع وراء تعاطي الكحول أثناء جائحة كوفيد 19-، جمهورية إيران الإسلامية }
\end{aligned}
$$

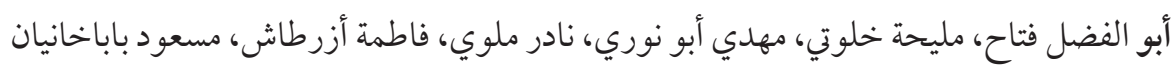

$$
\begin{aligned}
& \text { الخلاصة } \\
& \text { الخلفية: يعد ارتفاع تعاطي الكحول مشكلة صحية عامة مهمة، ومن الضروري فهم العوامل المرتبطة بهذا التعاطي. } \\
& \text { الأهداف: هدفت هذه الدراسة إلى تقييم العوامل الفردية والاجتهاعية المرتبطة بتعاطي الكحول أثناء جائحة مرض فيروس فئس كورونا } 2019 \\
& \text { (كوفيد-19 ) في جمهورية إيران الإسلامية. } \\
& \text { طرق البحث: في هذه الدراسة الكيفية، استخدمت عينات مقصودة لاختيار المشاركين في الدراسة من خلال مشاركة رابط المسحح عبر قنوات تطبيق }
\end{aligned}
$$

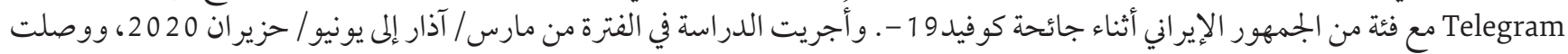

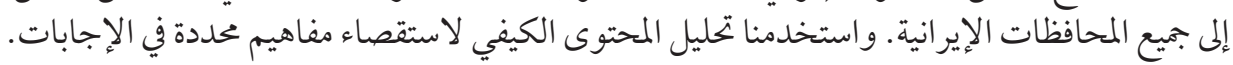

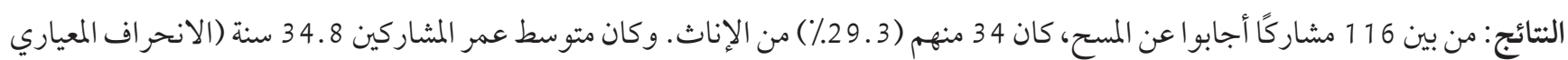

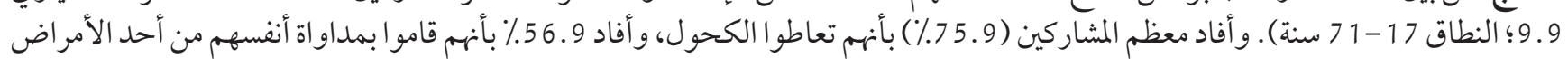

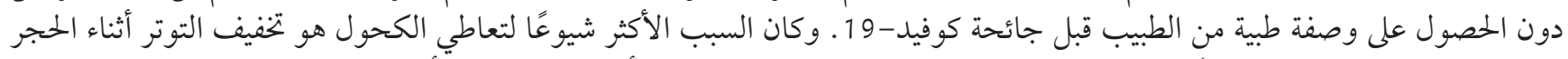

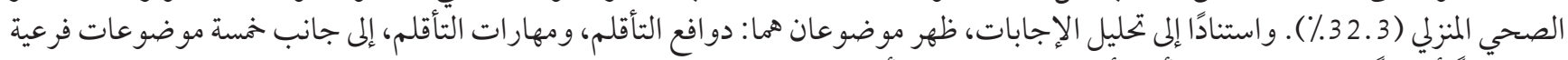

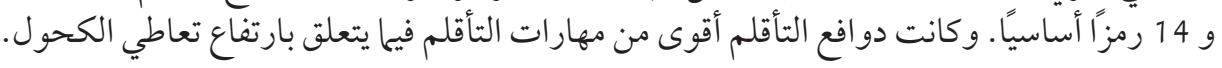

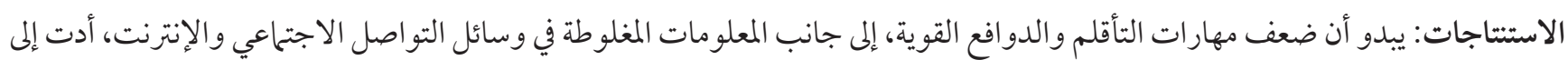

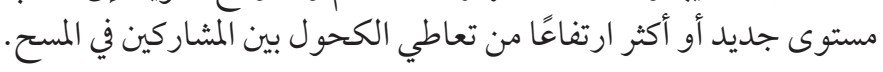




\section{References}

1. Lankarani KB, Afshari R. Alcohol consumption in Iran. Lancet. 2014;384(9958):1927-8. https://doi.org/10.1016/So1406736(14)62279-0.

2. Aghababaeian H, Araghi Ahvazi L, Ostadtaghizadeh A. The methanol poisoning outbreaks in Iran 2018. Alcohol Alcohol. 2019;54(2):128-30. https://doi.org/10.1093/alcalc/agzoo5

3. Global status report on alcohol and health 2018: executive summary. Geneva: World Health Organization; 2018 (https://www. who.int/publications/i/item/9789241565639, accessed 4 August 2021).

4. World Health Organization report on Iran's ranking in alcohol consumption. Geneva: World Health Organization; 2018 (https:// www.who.int/substance_abuse/publications/global_alcohol_report/profiles/irn.pdf?ua291\%20=1, accessed 3 October 2019).

5. The need to inform young people about the dangers of drinking alcohol. Tehran: Dana; 2019 (https://www.dana.ir/1559505/fa/, accessed 30 December 2019).

6. Rostami M. The coronavirus disease 2019 (COVID-19) and alcohol use disorders in Iran. Am J Mens Health. 2020;14(4):1557988320938610. https://doi.org/10.1177/1557988320938610

7. Mehrpour O, Sadeghi M. Toll of acute methanol poisoning for preventing COVID-19. Arch Toxicol. 2020;94(6):2259-60. https:// doi.org/10.1007/s00204-020-02795-2

8. Shokoohi M, Nasiri N, Sharifi H, Baral S, Stranges S. A Syndemic of COVID-19 and methanol poisoning in Iran: Time for Iran to consider alcohol use as a public health challenge? Alcohol. 2020;87:25-7. https://doi.org/10.1016/j.alcohol.2020.05.006

9. Aghababaeian H, Hamdanieh L, Ostadtaghizadeh A. Alcohol intake in an attempt to fight COVID-19: a medical myth in Iran. Alcohol. 2020;88:29-32. https://doi.org/10.1016/j.alcohol.2020.07.006

10. Haghdoost A, Emami M, Esmaili M, Soberinia A, NezhadGhaderi M, Mehrolhassani M. Survey of the status and causes of alcohol consumption: a case study of the epidemic alcohol poisoning in Rafsanjan in 2013. J Rafsanjan University Med Sci. 2015;13(10):991-1006 [In Farsi].

11. Delirrad M, Mohammadi AB. New methanol poisoning outbreaks in Iran following COVID-19 pandemic. Alcohol Alcohol. 2020;55(4):347-8. https://doi.org/10.1093/alcalc/agaa036

12. Lazarus RS, Folkman S. Stress, appraisal, and coping. New York, NY: Springer Publishing Company; 1984.

13. Esser MB, Sacks JJ, Sherk A, Karriker-Jaffe KJ, Greenfield TK, Pierannunzi C, et al. Distribution of drinks consumed by US adults by average daily alcohol consumption: a comparison of 2 nationwide surveys. Am J Prev Med. 2020;59(5):669-77. https://doi. org/10.1016/j.amepre.2020.04.018

14. Guidelines for the regulatory assessment of medicinal products for use in self-medication. Geneva: World Health Organization; 2000 (https://apps.who.int/iris/handle/10665/66154, accessed 4 August 2021).

15. Damari B, Chegeni M, Esmaili I, Sarrami H, Almadani H, Narenjiha H, et al. Status of alcohol consumption based on the self-report of Iran's industrial staff. Iran J Epidemiol. 2020;15(4):334-42 [In Farsi].

16. Nikfarjam A, Hajimaghsoudi S, Rastegari A, Haghdoost AA, Nasehi AA, Memaryan N, et al. The frequency of alcohol use in Iranian urban population: the results of a national network scale up survey. Int J Health Policy Manag. 2017;6(2):97-102. https://doi. org/10.15171/ijhpm.2016.103

17. Holahan CJ, Moos RH, Holahan CK, Cronkite RC, Randall PK. Drinking to cope, emotional distress and alcohol use and abuse: a ten-year model. J Stud Alcohol. 2001;62(2):190-8. https://doi.org/10.15288/jsa.2001.62.190

18. Kuntsche E, Knibbe R, Gmel G, Engels R. Why do young people drink? A review of drinking motives. Clin Psychol Rev. 2005;25(7):841-61. https://doi.org/10.1016/j.cpr.2005.06.002

19. Park CL, Armeli S, Tennen H. The daily stress and coping process and alcohol use among college students. J Stud Alcohol. 2004;65(1):126-35. https://doi.org/10.15288/jsa.2004.65.126

20. Razzaghi EM, Rahimi-Movaghar A, Hosseini M, Madani S, Chatterjee A. Rapid situation assessment of drug abuse in Iran (1998-1999). Short version of the final report. Tehran: Iranian Welfare Organization and United Nations International Drug Control Programme; 1999:38-59

21. Gunnell D, Appleby L, Arensman E, Hawton K, John A, Kapur N, et al. Suicide risk and prevention during the COVID-19 pandemic. Lancet Psychiatry. 2020;7(6):468-71. https://doi.org/10.1016/S2215-0366(20)30171-1

22. Collins RL, Martino SC, Kovalchik SA, D’Amico EJ, Shadel WG, Becker KM, et al. Exposure to alcohol advertising and adolescents' drinking beliefs: role of message interpretation. Health Psychol. 2017;36(9):89o. https://doi.org/10.1037/heaoooo521

23. Vosoughi S, Roy D, Aral S. The spread of true and false news online. Science. 2018;359(6380):1146-1151. https://doi.org/10.1126/ science.aap9559

24. Merrill JE, Thomas SE. Interactions between adaptive coping and drinking to cope in predicting naturalistic drinking and drinking following a lab-based psychosocial stressor. Addict Behav. 2013;38(3):1672-8. https://doi.org/10.1016/j.addbeh.2012.10.003

25. Najafi F, Hajizadeh M, Pasdar Y, Salimi Y, Hamzeh B, Karami Matin B, et al. Socioeconomic inequalities in tobacco, alcohol and illicit drug use: evidence from Iranian Kurds. East Mediterr Health J. 2020;26(10):1294-302. https://doi.org/10.26719/emhj.20.007 